\title{
Universities' pursuit of inclusion and its effects on professional staff: the case of the United Kingdom
}

\author{
Roxana-Diana Baltaru ${ }^{1}$
}

Published online: 17 July 2018

(C) The Author(s) 2018

\begin{abstract}
This paper explores the proliferation of non-academic professionals as a cultural response to universities' mission of inclusion. Departing from a neo-institutionalist perspective, the author argues that the diffusion of highly rationalised models of institutional action shapes universities as formal organisations who engage with new levels of professional expertise in the pursuit of goals and missions. The United Kingdom (UK) offers an illustrative example, the emergence of statutory equality duties on public institutions (race equality duty 2001, disability equality duty 2006 and gender equality duty 2007) nurturing an image of universities as strategic for the pursuit of demographic inclusion. Using yearly longitudinal data on $109 \mathrm{UK}$ universities from 2003 to 2011, the author shows that universities increase their professional staff in catering for demographic inclusion in terms of ethnicity and disability, revealing highly rationalised institutional responses to the aforementioned equality duties. The findings contribute to the neo-institutionalist literature drawing attention to the transformation of universities into organisational actors (i.e. highly integrated entities, strategically oriented towards the pursuit of formally articulated goals and targets), which contrasts with traditional conceptions of the university as an institution with a taken-for-granted societal role and loosely defined organisational backbone. The findings provide the impetuous for further empirical research into the role of professional staff as universities assimilate new goals and missions.
\end{abstract}

Keywords Non-academic professionals · Universities · Demographic inclusion - Equality duties · Formalisation · United Kingdom

\section{Introduction}

The increase in universities' non-academic professionals has become a salient issue, attracting much academic and public concern (Gornitzka and Larsen 2004; Ginsberg 2011). The existing

Roxana-Diana Baltaru

rdbalt@essex.ac.uk

1 Department of Sociology, University of Essex, Wivenhoe Park, Colchester, Essex CO43SQ, England 
literature at the European level situates this expansion against the backdrop of new goals and missions attributed to universities (Baltaru and Soysal 2017; see also Schneijderberg and Merkator 2013). These studies have called for more national-level investigations to pursue an in-depth understanding of how the broader cultural environment shapes local dynamics of administrative growth in higher education.

UK universities' commitment to demographic inclusion provides an illustrative case study into how diversifying missions shape the university sector. In this sense, the introduction of secondary legislation in the form of public sector equality duties (the race equality duty in 2001, the disability equality duty in 2006 and the gender equality duty in 2007) envisions universities as active agents in reducing discrimination and enhancing inclusion (McLaughlin 2007). This paper assesses the degree to which the UK universities' pursuit of inclusion in line with the aforementioned equality duties has fostered an increase in non-academic professionals. The UK university sector provides a highly relevant case study for understanding the proliferation of non-academic professionals, as the first European country where the number of administrative staff has already exceeded the one of academic staff (European Tertiary Education Register; ETER Project 2011).

First, the author provides an overview of the increase in professional staff as a major trend in UK universities and beyond. Second, the author engages with a cultural argument in order to illustrate how the pursuit of demographic inclusion has been shaped by broader cultural forces, namely the emergence of individual empowerment as an ideological direction and the diffusion of highly rationalised models of institutional action. Third, the author operationalises and empirically assesses the effect of demographic inclusion on universities' non-academic professionals, controlling for diversification in other university missions. Fourth, the findings are being discussed in relation to the wider literature documenting universities' transformation into organisations as they strategise for the pursuit of new goals and missions. The findings set up the premise for further empirical research investigating the role of professional staff in this process and call for a critical apprehension of universities' organisational change.

\section{Universities' higher education professionals}

The 2012 definitional change in the Standard Occupational Classification (SOC) used by the UK's official Higher Education Statistics Agency (HESA) signals a blurring of the boundaries between academic and non-academic professionals. As from 2012, the higher-level administrators previously referred to as "non-academic professionals" have been incorporated along traditional academic staff as "higher education professionals". The reclassification indicates an expanding perception of the role of higher education institutions (HEIs), whereby the core higher education professionals can be involved in the traditional activities of teaching and research but they may also perform other functions within the HE enterprise (e.g. student and staff development, research impact, global outreach). In this sense, it is specifically upper level administrators that enjoy an exceptionally high degree of professionalisation and expansion unlike other non-academic personnel such as those situated in lower technical and manual occupations (Universities UK 2013).

The restructuring of the HE personnel has been a subject of debate in various European countries; see Schneijderberg and Merkator (2013) for a comprehensive review of the literature. The empirical investigations converge in identifying a growing proportion of nonacademic personnel in professional positions [Whitchurch $(2004,2018)$ in the UK, Visakorpi 
(1996) in Finland, Blümel et al. (2010) and Krücken et al. (2013) in Germany and Gornitzka et al. (1998) and Gornitzka and Larsen (2004) in Norway]. Although previous research stresses the importance of understanding the factors associated with this pattern (Gumport and Pusser 1995), there is a profound lack of systematic investigations into the potential explanations.

The increase in universities' professional staff has been conceptualised against the backdrop of neo-liberal models of marketised higher education that emphasise student recruitment as an instrumental means for generating new sources of income (Jabbar et al. 2018). Universities are expected to employ more professional staff in strategic areas such as student recruitment (Lynch 2006) and to expand their human resources in order to deal with the operational needs associated with a larger student body (Gibb et al. 2012). However, recent European-level research has shown that the relationship between administrative staff and the overall increase in student numbers is overestimated (Baltaru and Soysal 2017). The alternative perspective puts forward the argument that the proliferation of non-academic professionals can be best understood against the backdrop of new goals and missions assimilated by universities (Krücken 2011) that foster the growing differentiation of functions at the organisational level (Schneijderberg and Merkator 2013).

This paper assesses this argument for the UK HE sector, by focusing on universities' mission of inclusion. The UK HE sector has been pursuing inclusion on two fronts. On the one hand, the widening of access to HE became increasingly important, with the participation rate increasing from about 6\% in 1963 to $49 \%$ by 2016 (Wyness 2010; Department for Education 2017). On the other hand, the pursuit of inclusion was expanded to cover university staff as diversity management became widely used in order to enhance egalitarian conditions in the labour market (Tatli et al. 2012). More recently, the rise of public sector equality duties (the race equality duty in 2001, the disability equality duty in 2006 and the gender equality duty in 2007) have acted as purveyors of legitimacy for universities' strategising for the pursuit of demographic inclusion.

The chronological overlap between the availability of HESA data on professional staff (early 2000s) and the outlined legal developments allows for a systematic investigation into how UK universities have changed in the process. Furthermore, the author engages with a neoinstitutionalist account and argues that universities' response to inclusion as a culturally prescribed goal was shaped by highly rationalised models of institutional action.

\section{Organising for inclusion: a neo-institutionalist account}

The increase in universities' professional staff has been conceptualised as an organisational response to goals and missions that have wider currency in the global environment (Krücken et al. 2009). The sociological institutionalist approach (also known as neo-institutionalism or the world society theory) provides the conceptual framework to situate organisational change in the global cultural context (DiMaggio and Powell 1991; Finnemore 1996; Meyer and Rowan 1977; Drori et al. 2006; Krücken and Drori 2009). Neo-institutionalist scholars highlight the importance of individual empowerment and rationalisation as "two prominent features of modern social thought and cultural ideology" (Frank et al. 1995, p. 360).

\section{Individual empowerment and universities' pursuit of inclusion}

Universities' mission of inclusion has been catalysed by the diffusion of individual empowerment as a legitimising ideological direction: "within and among societies, individuals 
mobilise around principles of actorhood and human rights" (Meyer 2000, p. 237; see also Frank and Meyer 2002; Ramirez et al. 2016). ${ }^{1}$ The human rights' provisions have consolidated this ideological direction through rights and freedoms for all (regardless of gender, race or other social status), enabling the image of individuals as empowered agents (Soysal 2012).

In the UK, the post-war consensus on non-discrimination was widely institutionalised in the provisions of equality law. The statutory equality duties from the early 2000s mark an important shift in the pursuit of individual empowerment from "negative equality law" (typically addressing issues of discrimination after they have occurred) to "positive equality duties" (where duty bearers are encouraged to play an anticipatory role in ensuring that individual's liberty is not damaged as a result of prejudice, but without the capacity or purpose to increase positive liberty) (McLaughlin 2007, p. 115; Feldman 2002). Positive equality duties have been specified with regard to race and ethnicity, disability and gender [see Race Relations Act 2000 (The National Archives 2000), Disability Act 2005 (The National Archives 2005) and Equality Act 2006 (The National Archives 2006)], and they were cumulated few years later as a generalised equality duty [see Equality Act 2010 (The National Archives 2010)].

Historically, the spread of individual empowerment discourses has led to new expectations surrounding the role of higher education, emphasising its function in linking the ideologies of human rights and progress (Meyer 2000). In this sense, positive equality duties act as a purveyor of legitimacy for institutions that are proactive in acknowledging and catering for students and staff that are protected under this legislation. It is crucial that we understand the ways in which universities adapt their provisions in response to external demands as the HE sector is hosting an increasingly diversified body of people. While the expansion of university services to meet the needs of a more diverse student body has been a reoccurring theme on the higher education agenda (Dearing Report 1997; Browne Report 2010), management models are increasingly required to meet the perceived development needs of staff (Gordon and Whitchurch 2007). The latest equality statistics show that from 2003/2004 to 2013/2014, there was a $90.9 \%$ increase in staff disclosed as disabled, a $39.6 \%$ increase in the proportion of UK staff from black and ethnic minority backgrounds and an over $3 \%$ increase in the proportion of female staff (Equality Challenge Unit 2015a). For the same time interval, the proportion of students disclosing a disability has increased by $85.2 \%$, there was an over $35 \%$ increase in the proportion of black and ethnic minority students, while female students continued to make for over a half of the student population (Equality Challenge Unit 2015b).

Virtually all UK universities are developing and monitoring equality and diversity (E\&D) objectives through policy documents and annual reports. Their formal commitment can be seen as a direct response to the "specific duties" concerning the implementation of equality schemes with regard to race and ethnicity, disability and gender. However, universities' approaches in terms of human resources are expected to vary depending on the needs of individual institutions. Gordon and Whitchurch (2007), for example, argue that some HEIs may choose to put additional responsibilities on academic staff (without pay or formal recognition) or create new professional support roles in areas such as learning support, staff development and student advice. Recent research, on the other hand, shows that universities indeed adopt similar organisational responses by expanding and diversifying the body of their professional staff (Schneijderberg and Merkator

\footnotetext{
${ }^{1}$ The principle of actorhood taps into the important assumption at the basis of the modern society, namely the ability of the individual to act autonomously and play a central constitutive role in the wider public life. This presupposes the centrality of the individual as an autonomous entity of high relevance to the collective good (Frank et al. 1995).
} 
2013; Baltaru and Soysal 2017). The author argues that in order to fully understand universities' organisational responses to the external demands, one must consider the broader cultural forces that shape universities as formal organisations.

\section{Rationalisation and formalisation in universities' pursuit of inclusion}

The enactment of "global institutionalised scripts of what a university is expected to be" does presuppose similarity not only in university missions but also in the ways in which such missions are catered for at the institutional level (Krücken et al. 2009, p. 5). Universities are part of a rationalised environment ${ }^{2}$ where they are portrayed as having the capacity to analyse resources and organise means-ends technologies in order to achieve clearly set goals and targets (Meyer and Bromley 2013). Such an environment fosters the transformation of the university into an "organisational actor": "an integrated, goal-oriented entity that is deliberately choosing its own actions and that can thus be held responsible for what it does" (Krücken and Meier 2006 p. 241). This transformation captures the new emphasis on the organisational level as a formative and independent level of decision-making for universities, entailing a shift in the attribution of responsibility from an individualised account to an organisational account (Krücken 2011). As such, the university has to explain and justify its actions (e.g. participating in an equality charter) or omissions (e.g. not taking part in a national student survey): "these decisions, which also include omissions or 'non-decisions', are negatively sanctioned by the rector and his or her deputies, who are more seen as heads of the organisation" (Krücken 2011, p. 5).

Krücken and Meier (2006) identify four signs of the transformation of universities into organisational actors: the proliferation of institutional-level accountability techniques, an overall trend towards universities defining their own goals and targets as opposed to centrally imposed tasks (or indeed, rearticulating such tasks as their own), the elaboration of formal organisational structures in line with goals and targets and the rise of the management profession characterised by growing demands of rationalisation on the organisation and its members. This contrasts sharply with earlier conceptualisations of the university as an institution with a taken-for-granted role in the pursuit of knowledge and a loosely defined organisational backbone: "caught between the academic profession and the state, there was not much legitimate space for institutional management" (Krücken and Meier 2006 p. 242).

The previously discussed equality duties in the UK public sector are illustrative of a standardising environment as duty bearers are expected to engage with highly rationalised approaches in order to minimise discrimination. Consider the example of the Disability Equality Duty coming into effect in 2006. Institutions are expected to articulate their commitment to the disability equality scheme in clearly defined objectives, devise an action plan (outlining the steps that the authority will engage with in pursuing these objectives), develop methods of assessing the impact of the proposed activities as well as collect and analyse data to assess the degree to which disability equality outputs were achieved as a result of the action plan.

\footnotetext{
${ }^{2}$ The glorification of rational action is widely reflected in the twentieth-century enthusiasm surrounding the universal applicability of science: "most aspects of modern society are organised around institutionalised and rationalised cultural theories managed in reality by scientists, lawyers, and other professionals" (Frank et al. 1995, p. 361; see also Drori et al. 2003). The diffusion of professional expertise in institutions of all types and from all over the world is symptomatic for this cultural direction "between the Otherhood that is involved in the scientific and professional contemplation of universal law and the practical world of actors, a thick layer of professionalism arises" (Meyer 2000, p. 241).
} 
From a neo-institutionalist perspective, the diffusion of formal organisation as a model of institutional identity fosters further formalisation in roles and functions, as universities "design new formal technical structures to meet taken-for-granted social norms" (Krücken et al. 2009, p. 19). This may put into perspective the growing body of higher education professionals (HEPROs) (Klumpp and Teichler 2008) in the middle ground between traditionally academic and administrative domains, a "third space" (Whitchurch 2008) where the increasing level of specialisation leads to blurred boundaries (Whitchurch 2004) and permeable borders (Kehm et al. 2008). The emergence of HEPROs in these areas underlines a human resource approach where new professional roles are being created (e.g. student support, staff development) as opposed to adding new responsibilities to the roles of academic staff (Gordon and Whitchurch 2007).

Strictly pertaining to inclusion, professional roles such as equality officers, staff counsellors, staff disability support, dignity and respect advisors are increasingly common across the UK HE landscape. However, the wave of professionalisation stemming from the pursuit of inclusion has a wider magnitude fostering formalisation in adjacent areas (e.g. human resource officers, academic advisors). An illustrative example is given by Teesside University's Equal Opportunities Policy (2008), subsequently updated to reflect the Equality Act 2010 (The National Archives 2010). Specialised teams such as the Equal Opportunities Committee are playing a central role in monitoring policy implementation, but institutional services at all levels are expected to articulate their commitment to widening participation (that includes market and publicity, access and admissions, staff recruitment, curriculum development and delivery, language use and broader legislation).

\section{Empirical implications}

Following the diffusion of formal organisation as a model of institutional identity and purpose (Meyer et al. 2006; Bromley and Meyer 2014), universities are likely expand their body of professtional staff in catering for demographic inclusion. Such dynamics should be especially evident in universities' responses to demographic inclusion in terms of race and ethnicity, disability and gender, following the role of statutory equality duties in nurturing the diffusion of highly rationalised approaches to organisation. Accordingly, the author hypothesises:

H1 The proportion of non-academic professionals is higher in universities that have an increasing number of students and staff from black and ethnic minority backgrounds.

H2 The proportion of non-academic professionals is higher in universities that have an increasing number of disabled students and staff.

H3 The proportion of non-academic professionals is higher in universities that have an increasing number of female students and staff.

The hypothesised relationships will be assessed while controlling for the total number of students capturing broader trends of massification in higher education (that includes the widening of access to students from different socio-economic backgrounds) (Schofer and Meyer 2005). The author will also control for diversification in universities' missions beyond inclusion, as universities are pursuing a wider array of goals possibly nurturing the proliferation of professional staff. In this sense, universities are increasingly strategising for internationalisation (Ayoubi and Massoud 2007), and they are orienting towards stronger 
research profiles in response to the Research Assessment Exercises ${ }^{3}$ (Yokoyama 2006; Deem 2010). Concomitantly, universities are adopting an entrepreneurial approach by looking to expand their sources of funding from external stakeholders such as governments, industry and the local community (Clark 1998).

The author controls for the reliance of universities on income from tuition fees and education contracts (e.g. research studentships) in order to capture the trends of marketisation in higher education (Lynch 2006) as opposed to organisational cultural forces (Bromley 2016; Hüther and Krücken 2016). From such a perspective, the increasingly deregulated and underfunded higher education sector poses a challenge to universities that seek to recruit more students in order to diversify their sources of revenue (Jabbar et al. 2018). It is possible that as universities become more reliant on income from tuition fees and education contracts, they will decide to employ more professional staff in strategic areas such as marketing and student recruitment. The model also controls for the total number of students, thereby accounting for the operational pressures that universities face as a result of increasing student numbers (Gibb et al. 2012).

\section{Data and methods}

Longitudinal data providing yearly information on staff numbers and all other organisational characteristics since 2003 is available from the HESA, the official agency for the collection of UK HE data funded principally through the subscriptions of various HEIs. The current paper explores the changes in non-academic professionals in 109 universities for which data are fully available, amounting for approximatively $80 \%$ of the UK HEIs with a university status. The HESA uses the national standard provided by the SOC in order to categorise occupational information. The data used in this paper captures the number of staff full-person or equivalent (headcounts), and it excludes atypical staff whose contracts last less than four consecutive weeks (e.g. guest lecturers, temporary staff contracted for short-term projects). The analysis is run on a longitudinal dataset with yearly data from 2003 to 2011, as from 2012, non-academic professionals are being merged with academic staff as higher education professionals in line with SOC changes in occupational coding.

A regression-based analytical technique is used in order to test the hypothesised associations, controlling for other institutional-level differences. The proportion of non-academic professionals represents the dependent variable. Although the HESA suggests merging the managerial, professional and technical staff in order to distinguish non-academic professionals from other administrative positions such as clerical and manual staff, the author follows the approach of Gornitzka and Larsen (2004) and reconstructs this category by excluding the technical staff. Therefore, the category of personnel to be explored in this study includes managers, senior administrators, planning and support personnel (e.g. student welfare workers, careers advisers, vocational training instructors, personnel and planning officers), services personnel (e.g. artistic, media, public relations, marketing and sports occupations) as well as other non-academic professionals (e.g. academic standards officers) but excludes building engineers, IT technicians and other technical staff.

\footnotetext{
${ }^{3}$ The Research Assessment Exercise (RAE) started being conducted by the UK funding councils every 5 years since 1986 as a tool of evaluating research quality in British HEIs. In 2008, it was followed by the Research Excellence Framework (REF).
} 
The level of demographic inclusion represents the principal predictor. It is operationalised starting from the legal directives surrounding the integration duties of UK public institutions. The author considers six variables indicating the proportions of students and staff (in total students and staff, respectively) with regard to ethnicity (black and ethnic minority students and staff), disability (disabled students and staff) and gender (female students and staff). The exploratory factor analysis has identified three dimensions of inclusion, explaining $81 \%$ of variance in the underlying construct: the ethnicity variables load the highest on the first factor $($ alpha $=.83)$, the gender indicators on the second factor $($ alpha $=.75)$ and the disability indicators on the third factor (alpha =.40). According to the Kaiser criterion, all factors are relevant in accounting for institutional variation in the underlying construct (eigenvalues $>1$ ). Based on this analysis, each pair of indicators has been cumulated across students and staff (e.g. the proportion of female students and staff in the total number of students and staff indicates "female inclusion", the proportion of black and ethnic minority students and staff in the total number of students and staff indicates "ethnic minority inclusion" and the proportion of disabled students and staff in the total number of students and staff indicates "disability inclusion"). However, note that the disability indicators have a low reliability coefficient $($ alpha $=.40)$. While it is possible that the proportion of disabled students and staff in the total number of students and staff will have an effect of its own (thus, it will be included in the analysis), the author will also address the potential differences between the effect of disabled students and that of disabled staff on professional staff. The analysis will be additionally run by separately including the proportion of disabled students in total students and the proportion of disabled staff in total staff.

The relationships between each type of demographic inclusion and the share of nonacademic professionals are estimated while controlling for the total number of students. ${ }^{4}$

The model controls for the broader diversification in universities' missions. First, the author accounts for international outlook by controlling for the proportion of non-UK students in total students. Second, the author accounts for the expansion in fundraising activity (beyond research grants and contracts), operationalised as all other income from services rendered to outside bodies (e.g. health and hospital authorities, local authorities, EU government bodies), including the supply of goods and consultancies, in total income. Third, the model controls for the proportion of research staff in total staff in order to capture the stregthening of universities' research profiles. The model also accounts for universities' reliance on students as customers, by controlling for universities' proportion of income derived from tuition fees (fees from credit-bearing courses) and education contracts (income from charities to cover tuition fees and bursaries in the context of research studentships), in total income.

Table 1 illustrates the descriptive statistics.

The empirical analysis is implemented in two steps. First, the author carries out a descriptive analysis of the HESA data in order to illustrate the pattern of change in HE staff relating to the average number of personnel between 2003 and 2011. Second, the author fits a series of fixed-effects (FE) regression models with lagged independent variables in order to empirically assess the proposed arguments. The data is set on a balanced panel with universities as the primary units of analysis $(N=109)$, observed yearly from 2003 to 2011 (981 observations). Having lagged the independent variables at time $T-1$, the total number of observations was

\footnotetext{
${ }^{4}$ The total number of students is strongly correlated with the total number of staff $(r=.63)$; thus, the model will only control for the total number of students in order to avoid multicollinearity.
} 
Table 1 Descriptive statistics

\begin{tabular}{|c|c|c|c|c|c|}
\hline Indicator & $M$ & SD & Min & Max & $N \times T$ \\
\hline$\%$ non-academic professionals & .16 & .04 & .04 & .33 & 872 \\
\hline Female inclusion (\% students and staff) & 61 & .08 & .34 & .99 & 872 \\
\hline Ethnic minority inclusion (\% student and staff) & .15 & .12 & .02 & .55 & 872 \\
\hline Disability inclusion (\% students and staff) & .07 & .03 & .02 & .33 & 872 \\
\hline Total number of students & 16,985 & 7626 & 1440 & 36,505 & 872 \\
\hline$\%$ income tuition fees and education contracts & .30 & .10 & .06 & .63 & 872 \\
\hline$\%$ international students & .23 & .12 & .00 & .71 & 872 \\
\hline$\%$ research staff & .34 & .09 & .02 & .59 & 872 \\
\hline$\%$ income from services rendered to outside bodies & .17 & .07 & .04 & .50 & 872 \\
\hline
\end{tabular}

Distributional issues have been addressed where appropriate through log transformations (non-academic professionals, ethnic minority inclusion and disability inclusion)

reduced to 872 . The Open University represents a major outlier for the students and staff data, and so, it has been excluded from the analysis. ${ }^{5}$

The Breusch and Pagan Lagrangian multiplier (LM) test has identified a significant level of institution-specific variance $\left(\chi^{2}=1503.23, p<.001\right)$, thus pooling the data deemed to be invalid. In order to control for the unobserved differences between universities, the author uses a FE model. Having lagged the independent variables by 1 year, the author was able to assess whether getting more students and staff from demographic backgrounds protected under the previously illustrated equality duties increases the proportion of non-academic professionals in total staff, net of institutional-level differences. The model, where $Y$ is the dependent variable (DV) with $i$ indicating the university and $t$ indicating the time, $X_{i(t-1)}$ exemplifies one lagged independent variable (IV) with coefficient $\beta_{1} ; \alpha_{i}$ is the unknown intercept for each university, and $u_{i}$ is the error term, becomes:

$$
Y_{i t}=\beta_{1} X_{i(t-1)}+\alpha_{i}+u_{i(t-1)}
$$

\section{Findings and discussion}

Figure 1 illustrates the evolution of academic staff and non-academic staff (that includes clerical staff, higher technical staff, manual staff and the category of interest to this paper: non-academic professionals), in the current sample, from 2003 to 2011. We can see that the average number of personnel has increased from about 2319 in 2003 to about 2646 in 2011, i.e. approximately 14\%. Although about $68 \%$ of this growth was due to the increase in academic staff, in 2011, the number of academic staff amounts to less than a half the total number of staff. In a more fine-grained analysis, we can see that the highest relative growth in the average number of personnel per university has been registered among non-academic professionals (27\%), followed by academic staff $(25 \%)$ and clerical staff $(11 \%)$. The average number of manual staff has decreased by $10 \%$, and that of technical staff has decreased by approximatively $2 \%$. The analysis shows a strong convergence with what has been found in other European countries and the earlier example of the USA.

Table 2 shows the results from the fixed-effects model with lagged independent variables predicting the proportion of non-academic professionals in total staff. The model introduces universities' level of demographic inclusion among students and staff (in terms of race and

\footnotetext{
${ }^{5}$ With regard to the number of students, the Open University displays values over ten times higher than the national average. Atypical values are also present for other indicators as in the case of staff data.
} 


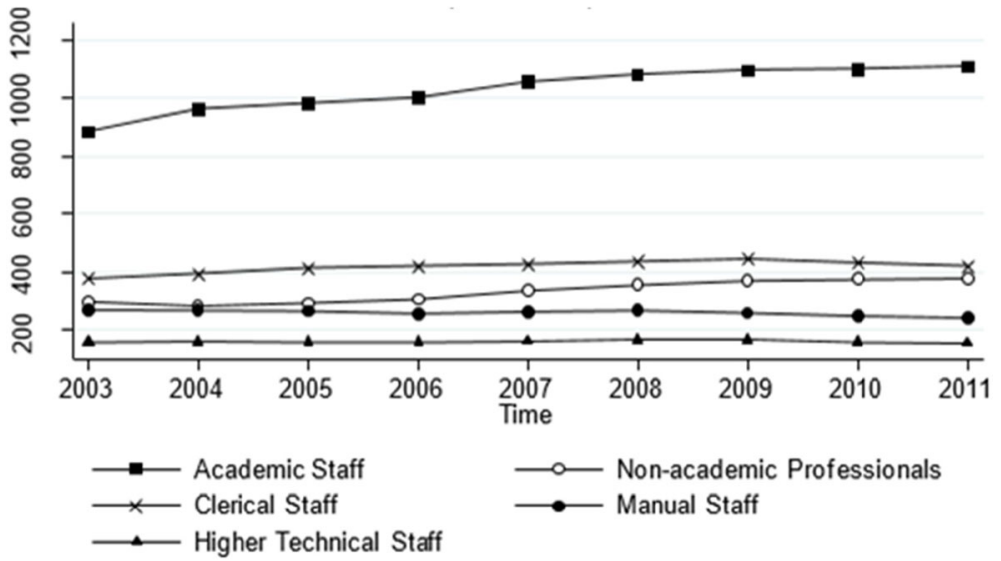

Fig. 1 The average number of personnel by category in UK universities (2003-2011)

ethnicity, disability and gender). The relationships are estimated while controlling for total students, international students in total students, income rendered from external services in total income, research staff in total staff and income from tuition fees and education contracts in total income.

In Table 2, we can clearly see that demographic inclusion in line with the equality duties on public institutions is propping up the proliferation of professional staff.

Table 2 Fixed-effects model with lagged independent variables predicting the proportion of non-academic professionals

\begin{tabular}{ll}
\hline Variables & Coefficients \\
\hline Constant & $-1.693^{* * *}$ \\
Ethnic minority inclusion & $(.464)$ \\
& $.245^{* * *}$ \\
Disability inclusion & $(.052)$ \\
Female inclusion & $.069^{*}$ \\
& $(.033)$ \\
Total students & .453 \\
International students & $(.654)$ \\
Income from services rendered to outside bodies & .011 \\
& $(.039)$ \\
Research staff & $.455^{*}$ \\
Income from tuition fees and education contracts & $(.211)$ \\
$R^{2}$ within universities & .091 \\
$R^{2}$ between universities & $(.283)$ \\
F-test & -.043 \\
$N$ (universities) & $(.255)$ \\
$N$ (observations) & $.419^{*}$
\end{tabular}

Robust standard errors are enclosed in parentheses

$* p<.05 ; * * * p<.001$ 
More precisely, the model estimates that a $1 \%$ increase in the proportion of students and staff from black and ethnic minority backgrounds leads to about $25 \%$ increase in the proportion of non-academic professionals $(B=.245, p<.001)$ (H1 confirmed). Concomitantly, a $1 \%$ increase in the proportion of disabled students and staff increases the proportion of nonacademic professionals by approximatively $7 \%(B=.069, p<.05)(\mathrm{H} 2$ confirmed). The inclusion of female students and staff is also positively associated with the share of nonacademic professionals, but insignificant $(B=.453, p>.05)$ ( $\mathrm{H} 3$ disconfirmed). The relative strength and significance of the relationships reflect the chronological introduction of the statutory equality duties. In this sense, the highly significant relationship capturing the impact of ethnic minority inclusion on professional staff pertains to the firstly implemented equality duty (the race and ethnicity equality duty in 2001), which was followed by the disability equality duty (in 2006), the last statutory duty being specified for gender (in 2007).

Notice that the inclusion of international students is another important aspect contributing to the proliferation of non-academic professionals $(B=.455, p<.05)$. The positive impact of international students on non-academic professionals is especially interesting as this can be observed while controlling for the share of income from tuition fees and education contracts. This finding shows that universities do not simply cater for international students as cash cows. We can see that universities getting more international students will expand their professional expertise regardless of their level of reliance on tuition fees and education contracts. This finding strengthens the neo-institutionalist argument according to which universities' engagement with professional expertise goes beyond the pressures of the markets, underlying the formalisation of the university as an organisation.

This finding can further help us interpret the independent effect of income from tuition fees and education contracts on professional staff. Controlling for demographic inclusion, total number of students, international students, research staff and income from externally rendered services, universities that become more reliant on income from tuition fees and education contracts tend to engage with more professional staff $(B=.419, p<.05)$. As the author has previously illustrated, it is unlikely that the impact of tuition fees and education contracts on professional staff stems from universities' competition for international students as customers. Moreover, the relationship may indicate that as universities are faced with new opportunities of expansion (in the UK case, the removal of the cap on tuition fees), they respond by further diversifying their professional expertise, thus consolidating their formal organisational structures. This echoes the experience of other European HE systems, where universities have responded to complex regulatory shifts by strengthening their organisational backbone (De Boer et al. 2007).

The model explains $22 \%$ of the variance in universities' non-academic professionals across time $\left(R^{2}\right.$ within universities $\left.=.22\right)$ which is a moderate amount. Figure 2 provides a visual illustration for the marginal effects. We can see that apart of research staff, all hypothesised indicators are positively associated with the share of professional staff (their coefficients are situated on the right hand of the vertical axis). However, only demographic inclusion (in terms of ethnicity and disability), international students and income from tuition fees and education contracts are significant.

Finally, given the low reliability coefficient between disabled students and disabled staff (alpha $<.70$ ), the analysis has been additionally run by separately considering the proportion of disabled students in total students and the proportion of disabled staff in total staff. Table 3 illustrates the results for disability inclusion and for all other significant coefficients, controlling for ethnic minority inclusion, female inclusion, total students, research staff and income from services rendered to outside bodies. 


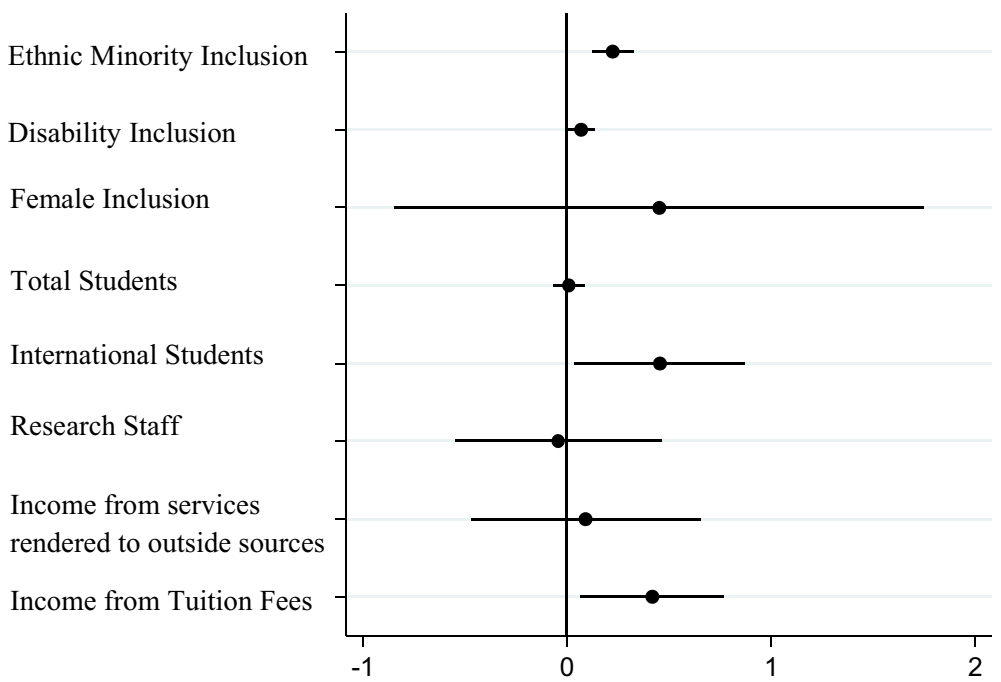

Fig. 2 Average marginal effects with $95 \%$ confidence interval

We can see that the positive relationship between disability inclusion and professional staff primarily reflects universities' responses to the increase in disabled students (Table 3, column A: $B=.063, p<.05$ ), while the inclusion of disabled staff is not significant on its own (Table 3, column B: $B=.026, p>.05$ ). This finding may point towards the pursuit of inclusion among disabled students being a reoccurring theme in higher education policy even before the 2006 disability equality duty. As early as the 1990s, the higher education sector was urged to "do more to adapt its teaching and learning strategies to meet the requirements of some students with disabilities" (Dearing Report 1997, p. 112). It is possible that the engagement with

Table 3 Fixed-effects model with lagged independent variables predicting the proportion of non-academic professionals

\begin{tabular}{lll}
\hline Variables & $(\mathrm{A})$ & \multicolumn{1}{c}{ (B) } \\
& Disabled students & Disabled staff \\
\hline Constant & $-1.729 * * *$ & $-1.741^{* * *}$ \\
& $(.463)$ & $.463)$ \\
Disability inclusion (column A for students; column B for staff) & $.063 *$ & .026 \\
& $(.027)$ & $.258^{* * *}$ \\
Ethnic minority inclusion & $.233 * * *$ & $(.054)$ \\
& $(.052)$ & $.449 *$ \\
International students & $.455^{*}$ & $(.211)$ \\
& $(.211)$ & $.421^{*}$ \\
Income from tuition fees and education contracts & $.437 *$ & $(.179)$ \\
& $(.177)$ & .22 \\
$R^{2}$ within universities & .22 & .00 \\
$R^{2}$ between universities & .00 & $10.21 * * *$ \\
F-test & $10.54 * * *$ & 109 \\
$N$ (universities) & 109 & 872 \\
$N$ (observations) & 872 & \\
\hline
\end{tabular}

Robust standard errors are enclosed in parentheses. Model controls are for female inclusion, total students, research staff and income from services rendered to outside bodies

$* p<.05 ; * * * p<.001$ 
professional staff in the 2000s has developed faster on the rosters of already existing formal structures responding to disability among students.

\section{Implications for universities as transforming institutions}

The findings are immediately relevant to the ongoing debate surrounding the increase in the number of non-academic professionals in UK universities. Projecting this pattern against the traditional university model (as an independent community of scholars pursuing knowledge as a good on its own, rather than as an integrated organisational entity negotiating a wider range of goals and missions) nurtures a binary perception of university staff as "academics vs. administrators" (Ginsberg 2011). However, this view is no longer an accurate representation of universities' organisational makeup, as higher education professionals are increasingly working on the borderline between academic staff and administration, leading to the blurring of boundaries between the two categories (Whitchurch 2008; Whitchurch 2018). This paper calls for a conceptualisation of professional staff that takes into account the increasing construction of universities as effective organisations that pursue goals and missions beyond teaching and research.

The contemporary university prides itself as an empowering institution, contributing to the public good by expanding its mission to accommodate the inclusion of students and staff from diverse demographic backgrounds (Meyer et al. 2006; Schofer and Meyer 2005). The UK HE sector aligns with this pattern, the emergence of statutory equality duties entailing further formalisation in universities' pursuit of inclusion. Universities are expected to adopt a proactive and anticipatory approach towards reducing discrimination by developing and implementing equality schemes at the institutional level. The statutory duties are portraying institutions as integrated actors, with the capacity to rationalise their resources and act systematically towards the pursuit of inclusion. The current analysis of the UK HE sector shows that it is the inclusion of demographic groups highlighted by the equality legislation that has nurtured an increase in universities' professional staff as opposed to the overall increase in student enrolments. The results bring to the fore empirical evidence for the argument that universities expand their professional structure in the rationalised pursuit of externally legitimised goals and missions.

Moreover, the institutionalisation of rationalised approaches to organisation has a profound impact at the organisational level. Universities increasingly codify their commitment to inclusion as scientific approaches to organisation by creating new roles and functions to be filled by professionals. That is, the elaboration of formal structures at the organisational level (e.g. equality and diversity offices, student support networks) indicates the strengthening of universities' organisational backbone by means of rationalisation (the articulation of university level goals and targets, the implementation of target-oriented action plans, the periodic assessment of outputs and impact, etc.) and standardisation (rationalised models of institutional action are increasingly assimilated by universities across the board). The findings align with the neo-institutionalist literature arguing that universities are transforming into organisational actors by providing their rational actorhood in catering to culturally prescribed goals and missions (Krücken and Meier 2006; Ramirez 2013; Ramirez and Christensen 2013).

The current findings provide the impetuous for two streams of research. First, the proliferation of professional staff as a culturally legitimised form of institutional action raises important questions about the degree to which the increase in non-academic professionals is functional in helping universities achieve their goals and targets (rather than a mere enactment of how a 
university "is expected to be") (Krücken et al. 2009, p. 5). Research in this area is particularly needed as highly influential models of higher education (purporting a vision of expansive, strategic and high-quality higher education) are coming under scrutiny more than ever before (Marginson 2016; Baltaru 2018). Second, universities' transformation into organisational actors fosters increasing similarity in university missions as well as in the ways in which universities are assimilating such missions at the institutional level. To the extent to which variation in universities' responses to environmental demands is a barometer for their ability to maintain a critical approach to normative and ideological directions, further research may explore the ways in which universities' catering for culturally prescribed goals and missions can be reconciled with their identity as "forums of critical thought" (Barnett 2000, p. 418; Deem and Eggins 2017).

Acknowledgements I would like to thank Yasemin Soysal (University of Essex) for all the feedback and conversations that have been of great inspiration throughout the process of developing this manuscript.

Funding information Baltaru acknowledges funding from the Council of Social and Economic Research (ES/ J500045/1).

Open Access This article is distributed under the terms of the Creative Commons Attribution 4.0 International License (http://creativecommons.org/licenses/by/4.0/), which permits unrestricted use, distribution, and reproduction in any medium, provided you give appropriate credit to the original author(s) and the source, provide a link to the Creative Commons license, and indicate if changes were made.

\section{References}

Ayoubi, R. M., \& Massoud, H. K. (2007). The strategy of internationalization in universities: a quantitative evaluation of the intent and implementation in UK universities. International Journal of Educational Management, 21(4), 329-349.

Baltaru, R. D. (2018). Do non-academic professionals enhance university performance? Reputation vs organisation. Studies in Higher Education, 1-14.

Baltaru, R. D., \& Soysal, Y. N. (2017). Administrators in higher education: organizational expansion in a transforming institution. Higher Education, 1-17.

Barnett, R. (2000). University knowledge in an age of supercomplexity. Higher Education, 40(4), 409-422.

Blümel, A., Kloke, K., Krücken, G., \& Netz, N. (2010). Restrukturierung statt expansion. Entwicklung im Bereich des nichtwissenschaftlichen Personals an deutschen Hochschulen. [Restructuring rather than expansion: developments in the field of non-academic staff in German universities]. Die Hochschule [The University], 20(2), 154-172.

Bromley, P. (2016). Policy and administration as culture: Organizational sociology and cross-national education trends. In K. Mundy, A. Green, R. Lingard, \& A. Verger (Eds.), The handbook of global policy-making in education (pp. 470-489). Chichester: Wiley-Blackwell.

Bromley, P., \& Meyer, J. W. (2014). 'They are all organizations': the cultural roots of blurring between the nonprofit, business, and government sectors. Administration \& Society, 49(7), 939-966.

Browne Report (2010). Securing a sustainable future for higher education — an independent review of higher education funding \& student finance. https:/www.gov.uk/government/uploads/system/uploads/attachment_data/file/422565 /bis-10-1208-securing-sustainable-higher-education-browne-report.pdf. Accessed 13 June 2017.

Clark, R. B. (1998). Creating entrepreneurial universities - Organizational Pathways of Transformation. Wagon Lane: Emerald Group Publishing Limited.

De Boer, H., Enders, J., \& Leisyte, L. (2007). Public sector reform in Dutch higher education: the organizational transformation of the university. Public Administration, 85(1), 27-46.

Dearing Report (1997). Higher education in the learning society. http://www.educationengland.org. uk/documents/dearing1997/dearing1997.html. Accessed 14 June 2017.

Deem, R. (2010). Herding the academic cats: the challenges of 'managing' academic research in the contemporary UK university. Perspectives: Policy and Practice in Higher Education, 14(2), 37-43.

Deem, R., \& Eggins, H. (Eds.). (2017). The university as a critical institution? Rotterdam: Sense Publishers. 
Department for Education. (2017). Participation rates in higher education: academic years 2006/2007 2015/2016. Retrieved from https://www.gov.uk/government/uploads/system/uploads/attachment_ data/file/648165/HEIPR PUBLICATION_2015-16.pdf. Accessed 10 Oct 2017.

DiMaggio, P. J., \& Powell, W. W. (Eds.). (1991). The new institutionalism in organizational analysis. Chicago: University of Chicago Press.

Drori, G. S., Meyer, J. W., Ramirez, O. F., \& Schofer, E. (2003). Science in the modern world polity: Institutionalization and globalization. Stanford: Stanford University Press.

Drori, G. S., Meyer, J. W., \& Hwang, H. (Eds.). (2006). Globalization and organization. World society and organizational change. Oxford: Oxford University Press.

Equality Challenge Unit (2015a). Equality in higher education — part 1: staff. Retrieved from http://www.ecu.ac.uk/wpcontent/uploads/2015/11/Equality-in-HE-statistical-report-2015-part-1-staff.pdf. Accessed 12 May 2016.

Equality Challenge Unit (2015b). Equality in higher education — part 2: students. Retrieved from http://www.ecu.ac. uk/wp-content/uploads/2015/11/Equality-in-HE-statistical-report-2015-part-2-students.pdf. Accessed 13 Aug 2017.

ETER Project. (2011). The European Tertiary Education Register. http://eter.joanneum.at/imdas-eter/ , data received 3 May 2015.

Feldman, S. (2002). Discrimination law. Oxford: Oxford University Press.

Finnemore, M. (1996). Norms, culture, and world politics: insights from sociology's institutionalism. International Organization, 50(2), 325-347.

Frank, D. J., \& Meyer, J. W. (2002). The profusion of individual roles and identities in the postwar period. Sociological Theory, 20(1), 86-105.

Frank, D. J., Meyer, J. W., \& Miyahara, D. (1995). The individualist polity and the prevalence of professionalized psychology: a cross-national study. American Sociological Review, 60(3), 360-377.

Gibb, A., Haskins, G., Hannon, P., \& Robertson, I. (2012). Leading the entrepreneurial university. The National Centre for Entrepreneurship in Education (NCEE). http://eureka.sbs.ox.ac.uk/4861/1/EULP_-_LEADERS_ PAPER_final_dec_19.pdf. Accessed 16 May 2016.

Ginsberg, B. (2011). The fall of the faculty: The rise of the all-administrative university and why it matters. Oxford: Oxford University Press.

Gordon, G., \& Whitchurch, C. (2007). Managing human resources in higher education: the implications of a diversifying workforce. Higher Education Management and Policy, 19(2), 135-155.

Gornitzka, §., \& Larsen, I. M. (2004). Towards professionalisation? Restructuring of administrative work force in universities. Higher Education, 47(4), 455-471.

Gornitzka, Å., Kyvik, S., \& Larsen, I. M. (1998). The bureaucratization of universities. Minerva, 36(1), 21-47.

Gumport, P. J., \& Pusser, B. (1995). A case of bureaucratic accretion: context and consequences. The Journal of Higher Education, 66(5), 493-520.

Hüther, O. \& Krücken, G. (2016). Nested organizational fields: isomorphism and differentiation among European universities. In: E.P. Berman, \& C. Paradeise (Eds.) The university under pressure. Edition: Research in the sociology of organizations Vol. 46 (pp. 53-83). Emerald.

Jabbar, A., Analoui, B., Kong, K., \& Mirza, M. (2018). Consumerisation in UK higher education business schools: higher fees, greater stress and debatable outcomes. Higher Education, 76(1), 85-100.

Kehm, B. M., Mayer, E., \& Teichler, U. (2008). Resümee der Herausgeber. Auf dem Weg zum Ausbau und zur Stabilisierung der Hochschulprofessionen [Summary of the editors. On the road to the expansion and stabilisation of higher education professions]. In B. M. Kehm, E. Mayer, \& U. Teichler (Eds.), Hochschulen in neuer Verantwortung: Strategisch, überlastet, divers? [Universities in new responsibilities: strategic, overloaded, diverse?] (pp. 198-200). Bonn: Lemmens.

Klumpp, M., \& Teichler, U. (2008). Experten für das Hochschulsystem: Hochschulprofessionen zwischen Wissenschaft und Administration [Experts in higher education: professions between science and administration]. In B. M. Kehm, E. Mayer, \& U. Teichler (Eds.), Hochschulen in neuer Verantwortung: Strategisch, überlastet, divers? [Universities in new responsibilities: Strategic, overloaded, diverse?] (pp. 169-171). Bonn: Lemmens.

Krücken, G. (2011). A European perspective on new modes of university governance and actorhood. Research and occasional paper series: CHSE.17.11. Retrieved from http://files.eric.ed.gov/fulltext/ED529727.pdf. Accessed 12 Jan 2016.

Krücken, G., \& Drori, G. S. (Eds.). (2009). World society. The writings of J. W. Meyer. Oxford: Oxford University Press.

Krücken, G., \& Meier, F. (2006). Turning the university into an organizational actor. In G. S. Drori, J. W. Meyer, \& H. Hwang (Eds.), Globalization and organization: World society and organizational change (pp. 241257). Oxford: Oxford University Press.

Krücken, G., Blümel, A., \& Kloke, K. (2009). Towards organizational actorhood of universities: occupational and organizational change within German university administrators. Discussion Papers. FÖV 48. www. foev-speyer.de/files/de/fbpdf/DP-048.pdf. Accessed 20 Sept 2016.

Krücken, G., Blümel, A., \& Kloke, K. (2013). The managerial turn in higher education? On the interplay of organizational and occupational change in German academia. Minerva, 51(4), 417-442. 
Lynch, K. (2006). Neo-liberalism and marketization: the implications for higher education. European Educational Research Journal, 5(1), 1-17.

Marginson, S. (2016). The dream is over: The crisis of Clark Kerr's California idea of higher education. California: University of California Press.

McLaughlin, E. (2007). From negative to positive equality duties: the development and constitutionalization of equality provisions in the UK. Social Policy and Society, 6(1), 111-121.

Meyer, J. W. (2000). Globalization: sources and effects on national states and societies. International Sociology, $15(2), 235-250$.

Meyer, J. W., \& Bromley, P. (2013). The worldwide expansion of organization. Sociological Theory, 31(4), 366-389.

Meyer, J. W., \& Rowan, B. (1977). Institutionalized organizations: formal structure as myth and ceremony. American Journal of Sociology, 83(2), 340-363.

Meyer, J. W., Ramirez, O.F., Frank, J.D., \& Schofer, E. (2006). Higher education as an institution. Center of Democracy, Development and the Rule of Law: Stanford. CDRL working papers. https://www.academia. edu/14876375/Higher_Education_as_an_Institution. Accessed 17 June 2016.

Ramirez, O. F. (2013). World society and the university as formal organization. Journal of Education, 1(1), 124-153.

Ramirez, O. F., \& Christensen, T. (2013). The formalization of the university: rules, roots, and routes. Higher Education, 65(6), 695-708.

Ramirez, O. F., Bromley, P., \& Russel, S. G. (2016). The valorization of humanity and diversity. In Y-K. Cha, J. Gundara, S-H. Ham, \& M. Lee (Eds.), Multicultural education in glocal perspectives - Policy and Institutionalization (pp. 23-39). Singapore: Springer.

Schneijderberg, C., \& Merkator, N. (2013). The new higher education professionals. In B. M. Kehm \& U. Teichler (Eds.), The academic profession in Europe: New tasks and new challenges (pp. 53-87). London: Springer.

Schofer, E., \& Meyer, W. J. (2005). The worldwide expansion of higher education in the twentieth century. American Sociological Review, 70(6), 898-920.

Soysal, Y. N. (2012). Postnational citizenship: reconfiguring the familiar terrain. In E. Amenta, K. A. Nash, \& A. Scott (Eds.), The Wiley-Blackwell companion to political sociology (pp. 383-397). Malden: Wiley-Blackwell.

Tatli, A., Vassilopoulou, J., Ariss, A., \& Özbilgin, M. (2012). The role of regulatory and temporal context in the construction of diversity discourses: the case of UK, France and Germany. European Journal of Industrial Relations, 18(4), 293-308.

Teesside University. (2008). Equal opportunities policy. United Kingdom. Retrieved from https://www.tees.ac. uk/docs/DocRepo/Human\%20Resources\%20Policies\%20and\%20Procedures/Equal\%20Opportunities\%20 Policy.doc. Accessed 11 May 2014.

The National Archives. (2000). Race relations (Amendment) act. Retrieved from http://www.legislation.gov. uk/ukpga/2000/34/contents. Accessed 22 June 2016.

The National Archives. (2005). Disability Discrimination Act. Retrieved from http://www.legislation.gov. uk/ukpga/2005/13/contents. Accessed 22 June 2016.

The National Archives. (2006). The equality act. Retrieved from http://www.legislation.gov.uk/ukpga/2006 /3/notes/contents. Accessed 22 June 2016.

The National Archives. (2010). The equality act. http://www.legislation.gov.uk/ukpga/2010/15/contents. Accessed 22 June 2016.

Universities UK. (2013). Patterns and trends in UK higher education. In collaboration with HESA (Higher Education Statistics Agency). Retrieved from http://www.universitiesuk.ac.uk/policy-andanalysis/reports/Documents/2013/patterns-and-trends-uk-higher-education-2013.pdf. Accessed 12 July 2016.

Visakorpi, J. K. (1996). Academic and administrative interface: application to national circumstances. Higher Education Management and Policy, 8(2), 37-40.

Whitchurch, C. (2004). Administrative managers-a critical link. Higher Education Quarterly, 58(4), $280-298$.

Whitchurch, C. (2008). Shifting identities and blurring boundaries: the emergence of third space professionals in UK higher education. Higher Education Quarterly, 62(4), 377-396.

Whitchurch, C. (2018). Being a higher education professional today. Working in Third Space. In C. Bossu \& N. Brown (Eds.), University development and administration. Professional and support staff in higher education. Dordrecht: Springer.

Wyness, G. (2010). Policy changes in UK higher education funding, 1963-2009. DoQSS Working Paper No. 1015. Institute of Education: University of London.

Yokoyama, K. (2006). The effect of the research assessment exercise on organisational culture in English universities: collegiality versus managerialism. Tertiary Education and Management, 12(4), 311-322. 